\title{
ASSESSING THE IMPACT OF LEAN METHODS IN MINING DEVELOPMENT PROJECTS
}

\author{
Cristóbal Baladrón ${ }^{1}$ and Luis F. Alarcón ${ }^{2}$
}

\begin{abstract}
One of the main challenges that developing countries face is the need to increase productivity. In Chile, the most important productivity gap in both mining and construction industries is the lack of operational efficiency, caused mainly by the low adoption of advance management methods. Hence, considering the need to increase productivity through operational efficiency, lean production emerges as a management system with the objective to create value while eliminating waste, and continuously seek operational excellence. This research evaluates the impacts of the implementation of lean methods in an underground mining development project in the execution phase, which will help to better understand to what extent these methodologies can affect the performance of this type of projects. This research indicates that the implementation of lean methods in an underground mining development project had a statistical significant improvement of the mean for all indicators studied. Likewise, the implementation produced a statistically significant reduction of the variability for some indicators; moreover, there is a considerable reduction in the coefficient of variation $(\mathrm{CV})$, which indicates more stable processes. In addition, this research demonstrates that there is a statistically significant correlation between the percent of plan completed and its coefficient of variation.
\end{abstract}

Keywords: lean construction, lean mining, mining development project, percent of plan completed (PPC), variability.

\section{INTRODUCTION}

One of the main challenges that face developing countries is the need to increase productivity, since it is proven that productivity is the factor that better explains the difference of Gross Domestic Product per capita between countries. Out of all of the industries in Chile, mining has the highest relative productivity rate, reaching $68 \%$ of the productivity of Australian mining companies. Regarding construction in Chile, this productive sector has a relative productivity of $38 \%$ compared with the same industry in the United States (McKinsey and Company 2013).

Given this scenario, there are significant productivity gaps that need to be addressed in order to increase the country's competitiveness. When identifying these gaps, operational efficiency is considered to have the most potential to improve in both the mining and construction industries: it could raise relative productivity in mining and construction by $27 \%$ and $32 \%$, respectively. The main causes of low operational efficiency are low adoption of advance management methods, low level of standardization of

1 MSc Student, Department of Construction Engineering and Management, Pontificia Universidad Católica de Chile, Av. Vicuña Mackenna 4860, Edificio San Agustín 3er Piso, Macul, Santiago, Chile, Phone +56 22354 4244, cbaladr1@uc.cl

2 Professor, Department of Construction Engineering and Management, Pontificia Universidad Católica de Chile, Av. Vicuña Mackenna 4860, Edificio San Agustín 3er Piso, Macul, Santiago, Chile, Phone +56 22354 4244, lalarcon@ing.puc.cl 
planning processes, fragmentation of the phases of the projects, lack of training for workers and sub-optimal organization of work (McKinsey and Company 2013).

\section{BACKGROUND}

Considering the need to increase productivity through operational efficiency, different operational management methods that could be relevant must be explored. In this search emerges lean production, which is the management system used in the Toyota Production System that changed the concept of production defined in the craft and mass production systems. This philosophy seeks to deliver to the costumer what is needed, in the amount needed and when it is needed, based on a just-in-time delivery method (Shah \& Ward 2007; Womack \& Jones 1996; Womack et al. 1990).

The principles that sustain lean philosophy are: (1) reducing variability and (2) increasing value adding activities (Womack \& Jones 1996). This philosophy has been applied mainly in manufacturing and health (Ballard 2005; Ballard \& Howell 1994; Ballard 2000; Koskela 1992), however, there are other industries that have adopted it slowly and belatedly, among which are the construction and mining industries (Ballard 2005; Castillo et al. 2015; De Valence 2005).

On the implementation of lean in mining, there is literature on the theoretical applicability of the lean principles (Yingling et al. 2000; Wijaya et al. 2009; Hattingh \& Keys 2010) and implementations in mining operations and projects (Ade \& Deshpande 2012; Castillo et al. 2015; Dunstan et al. 2006; Klippel et al. 2008b; Klippel et al. 2008a). However, there are few reported cases of implementation in mining development projects (Dunstan et al. 2006; Castillo et al. 2015). Nevertheless this type of projects is identified as the area that presents the greatest potential for lean implementation in the mining industry (Loow 2015).

In lean construction, one widely used tool is the Last Planner System (LPS), which is a planning and control system that emerges from the lean principles applied in a construction environment. This system is sustained by commitments, which are given by the workers about the work they do (Ballard \& Howell 1994; Ballard 2000). The study of the application of the LPS in industrial mining projects has been limited (Leal 2010), although it is noticed to be very applicable (Castillo et al. 2015; Leal 2010). In lean construction, specifically in commercial and residential project, there has been found a strong correlation between the percent of plan completed (PPC) and its coefficient of variation (CV) (Alarcón et al. 2008), but this has not yet been proven true in mining development projects.

\section{RESEARCH METHODOLOGY}

To develop this research, a case study methodology was used. This methodology was chosen because it allows the authors: (1) to study the singularities of a particular case (Arzaluz 2005; Yin 2003; Simons 2011); (2) to utilize different techniques simultaneously, such as documents, reports, interviews, surveys, among others (Arzaluz 2005; Goode \& Hatt 2008; Yin 2003); and (3) to conduct quantitative, qualitative or mixed research (Yin 2003). Additionally, the objective of the research is to study a phenomenon in depth, considering the particularities of a single case (Arzaluz 2005; Simons 2011; Yin 2003) and the research focus is contemporary, rather than historical (Schell 1992; Yin 2003). 


\subsection{Selection of case study}

One underground mining development project was selected in order to evaluate the impacts of the lean implementation. The amount of data gathered in this research permitted us to perform inferential statistical analysis and correlational analysis, which provided sturdiness to the analysis carried out. This implementation took place during the execution phase of the project, i.e. under construction, due to the owner's need to improve contractor productivity.

\subsection{Implementation plan}

This implementation took place in an underground mining development project, developed by an international construction company, which carried out tunnelling work, specifically at the production, caving, intermediate transport, ventilation and crushing levels. The scope of the development work was the development of horizontal underground tunnelling for a new mine.

This implementation lasted twelve months and it was divided in three stages: diagnosis, implementation and control, as illustrated in Figure 1. In the diagnosis stage, the current state of the project was established. Then, in the second stage, the lean methods chosen were implemented for a period of six months. Finally, in the control stage, the impact of the implementation was established.

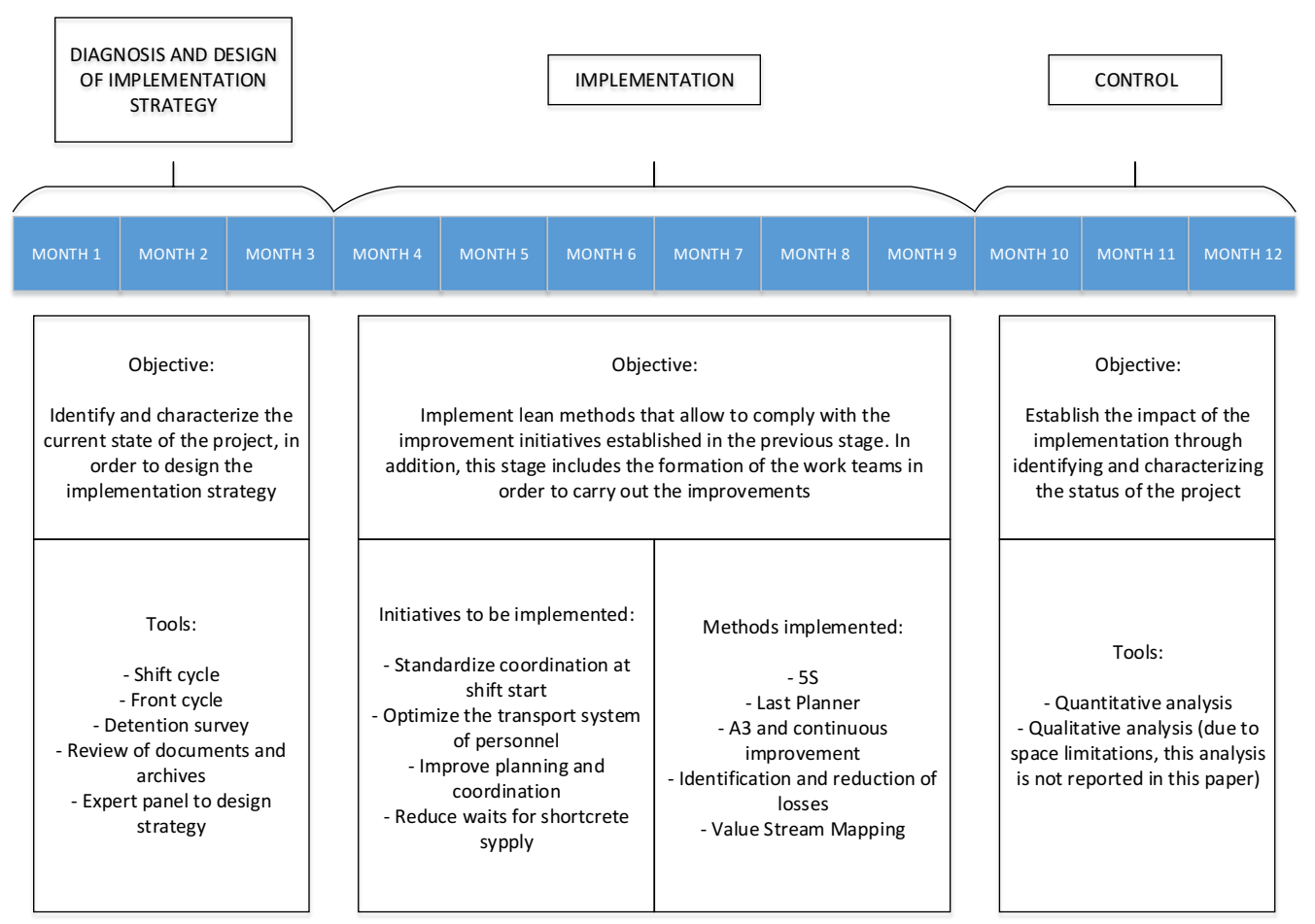

Figure 1: Research and implementation scope and timeline

\subsection{Selection of indicators}

The indicators analysed were selected considering literature review, expert opinion and the capability of monitoring them. Also, these indicators were chosen because it was possible to keep track of them during the diagnosis and control stages, and they were directly related to productivity. The quantitative data was obtained from field samples and reports from the contractor, as illustrated in Table 1. 
Table 1: Description of indicators

\begin{tabular}{|c|c|c|c|c|}
\hline $\begin{array}{l}\text { Theoretical } \\
\text { proposition }\end{array}$ & Variable & Definition & $\begin{array}{l}\text { Operational } \\
\text { measurement }\end{array}$ & $\begin{array}{l}\text { Source of } \\
\text { evidence }\end{array}$ \\
\hline $\begin{array}{l}\text { 1. Best results } \\
\text { (mean } \\
\text { improvement) }\end{array}$ & \multirow[t]{2}{*}{$\begin{array}{l}\text { Workable } \\
\text { time }\end{array}$} & \multirow{2}{*}{$\begin{array}{l}\text { Time of the day that } \\
\text { the worker is in front } \\
\text { and that could } \\
\text { potentially be used in } \\
\text { productive work }\end{array}$} & \multirow{2}{*}{$\begin{array}{l}\text { Time the worker is } \\
\text { on the front, } \\
\text { considering a } 12- \\
\text { hour day }\end{array}$} & \multirow[t]{2}{*}{$\begin{array}{l}\text { On-field } \\
\text { samples }\end{array}$} \\
\hline \multirow{4}{*}{$\begin{array}{l}\text { 2. More stable } \\
\text { results (variability } \\
\text { reduction) }\end{array}$} & & & & \\
\hline & \multirow[t]{2}{*}{$\begin{array}{l}\text { Daily } \\
\text { physical } \\
\text { progress }\end{array}$} & $\begin{array}{l}\text { Number of advanced } \\
\text { linear meters daily }\end{array}$ & $\begin{array}{c}\text { Number of } \\
\text { advanced meters } \\
\text { per day }\end{array}$ & $\begin{array}{l}\text { Contractor } \\
\text { reports }\end{array}$ \\
\hline & & Number of daily blasts & $\begin{array}{l}\text { Number of daily } \\
\text { blasts }\end{array}$ & $\begin{array}{l}\text { Contractor } \\
\text { reports }\end{array}$ \\
\hline & $\begin{array}{l}\text { Program } \\
\text { completion }\end{array}$ & $\begin{array}{l}\text { Relationship between } \\
\text { the executed and the } \\
\text { programmed }\end{array}$ & PPC & $\begin{array}{l}\text { On-field } \\
\text { samples }\end{array}$ \\
\hline $\begin{array}{l}\text { 3. Strong } \\
\text { relationship } \\
\text { between PPC and } \\
\text { its CV }\end{array}$ & PPC & $\begin{array}{l}\text { Relationship between } \\
\text { activities completed } \\
\text { and planned }\end{array}$ & $\begin{array}{c}\text { PPC: Activities } \\
\text { Completed / } \\
\text { Planned Activities }\end{array}$ & $\begin{array}{l}\text { On-field } \\
\text { samples }\end{array}$ \\
\hline
\end{tabular}

\section{ANALYSIS OF RESUlts: QUANTITATIVE ANALYSIS}

Two methods of quantitative analysis were used: inferential statistics and correlation. In this investigation, inferential statistics is related to the hypothesis test (Pardo \& San Martín 1998) and it was used two parametric tests: (1) test T for equality of means, which allows determining if two samples have equal mean, and (2) test of Levene of equality of variance, which allows determining if two samples have the same variance.

Statistical correlation is defined as the degree of association, similarity or joint variation between two or more variables of a population. In particular, in order to be able to quantify the degree of correlation between the variables, Pearson's correlation coefficient was used. The absolute value of the Pearson correlation coefficient indicates the strength of the correlation, while the sign indicates the direction of the correlation (Pardo \& San Martín 1998).

\section{IMPLEMENTATION RESULTS}

\subsection{Project performance}

Table 2 illustrates a summary of the descriptive statistics in the diagnosis and control stages. 
Table 2: Indicators in the diagnosis and after the implementation

\begin{tabular}{|c|c|c|c|c|c|}
\hline & $\begin{array}{l}\text { Descriptive } \\
\text { statistics }\end{array}$ & $\begin{array}{l}\text { Workable } \\
\text { time }\end{array}$ & $\begin{array}{l}\text { Daily } \\
\text { physical } \\
\text { progress } \\
\text { (meters) }\end{array}$ & $\begin{array}{l}\text { Daily } \\
\text { physical } \\
\text { progress } \\
\text { (blasts) }\end{array}$ & $\begin{array}{c}\text { Program } \\
\text { completion }\end{array}$ \\
\hline \multirow[t]{4}{*}{ Diagnosis } & Mean & 5.75 hours & $\begin{array}{c}12.7 \\
\text { meters }\end{array}$ & 4.8 blasts & $60.9 \%$ \\
\hline & $\begin{array}{l}\text { Standard } \\
\text { deviation }\end{array}$ & 1.43 hours & $\begin{array}{c}6.32 \\
\text { meters }\end{array}$ & 1.84 blasts & $4.9 \%$ \\
\hline & $\mathrm{CV}$ & $25 \%$ & $50 \%$ & $38 \%$ & $8.1 \%$ \\
\hline & Sample size & 98 & 92 & 90 & 3 \\
\hline \multirow[t]{4}{*}{ Implementation } & Mean & 6.67 hours & $\begin{array}{c}20.5 \\
\text { meters }\end{array}$ & 6.7 blasts & $81.4 \%$ \\
\hline & $\begin{array}{l}\text { Standard } \\
\text { deviation }\end{array}$ & 0.98 hours & $\begin{array}{c}5.49 \\
\text { meters }\end{array}$ & 1.76 blasts & $7.9 \%$ \\
\hline & $\mathrm{CV}$ & $15 \%$ & $27 \%$ & $26 \%$ & $9.7 \%$ \\
\hline & Sample size & 41 & 88 & 88 & 3 \\
\hline \multirow{3}{*}{$\begin{array}{c}\text { Percent variation } \\
\text { of mean (diagnosis } \\
\text { vs. } \\
\text { implementation) }\end{array}$} & Mean & $+16 \%$ & $+61 \%$ & $+40 \%$ & $+34 \%$ \\
\hline & $\begin{array}{l}\text { Standard } \\
\text { deviation }\end{array}$ & $-31 \%$ & $-13 \%$ & $-4 \%$ & $+61 \%$ \\
\hline & $\mathrm{CV}$ & $-40 \%$ & $-46 \%$ & $-32 \%$ & $+30 \%$ \\
\hline
\end{tabular}

Table 3 summarizes the inferential statistical tests performed, where "Yes" means that there is a statistical significant difference of the value of the indicator when comparing the diagnosis and control, "No" means that there is not such statistical significant, and "N.A." means that it was not possible to perform the tests due to small sample sizes. Considering a level of significance of 0.05 , there is an improvement of means for all the indicators and an improvement of variance in the indicator of workable time.

Table 3: Statistical results

\begin{tabular}{ccccc}
\hline & Workable time & $\begin{array}{c}\text { Daily } \\
\text { physical } \\
\text { progress } \\
\text { (meters) }\end{array}$ & $\begin{array}{c}\text { Daily } \\
\text { physical } \\
\text { progress } \\
\text { (blasts) }\end{array}$ & $\begin{array}{c}\text { Program } \\
\text { completion }\end{array}$ \\
\hline Equality of means test & Yes & Yes & Yes & N.A. \\
\hline Equality of variance test & Yes & No $(0.172)$ & No $(0.909)$ & N.A. \\
\hline
\end{tabular}

Moreover, the reduction in the $\mathrm{CV}$ shows that the indicators became more stable; therefore, it can be infer that the processes became more stable. Figure 2 illustrates the histograms and boxplot for the indicators analysed. Due to the small sample size used in the analysis of the indicator "Program completion", histograms and box plot of this indicator are not displayed. 


\begin{tabular}{|l|l|l|l|}
\hline Indicator & Histograms & Box plot \\
\hline $\begin{array}{l}\text { Workable } \\
\text { time }\end{array}$ & N.A. & & \\
\hline $\begin{array}{l}\text { Daily } \\
\text { physical } \\
\text { progress } \\
\text { (meters) }\end{array}$
\end{tabular}

Figure 2: Histograms and boxplot diagrams of indicators

\subsection{Correlation between PPC and its coefficient of variation}

The activities tracked correspond to all of those that conform the drill and blast cycle, i.e., surveying, drilling, charging explosives, blasting, loading, hauling, scaling and bolting. The PPC was calculated daily and then, an average weekly PPC was calculated. The evolution of the average of the weekly PPC and its CV is shown in Figure 3. For this analysis, 21 weeks of PPC measurements were considered.

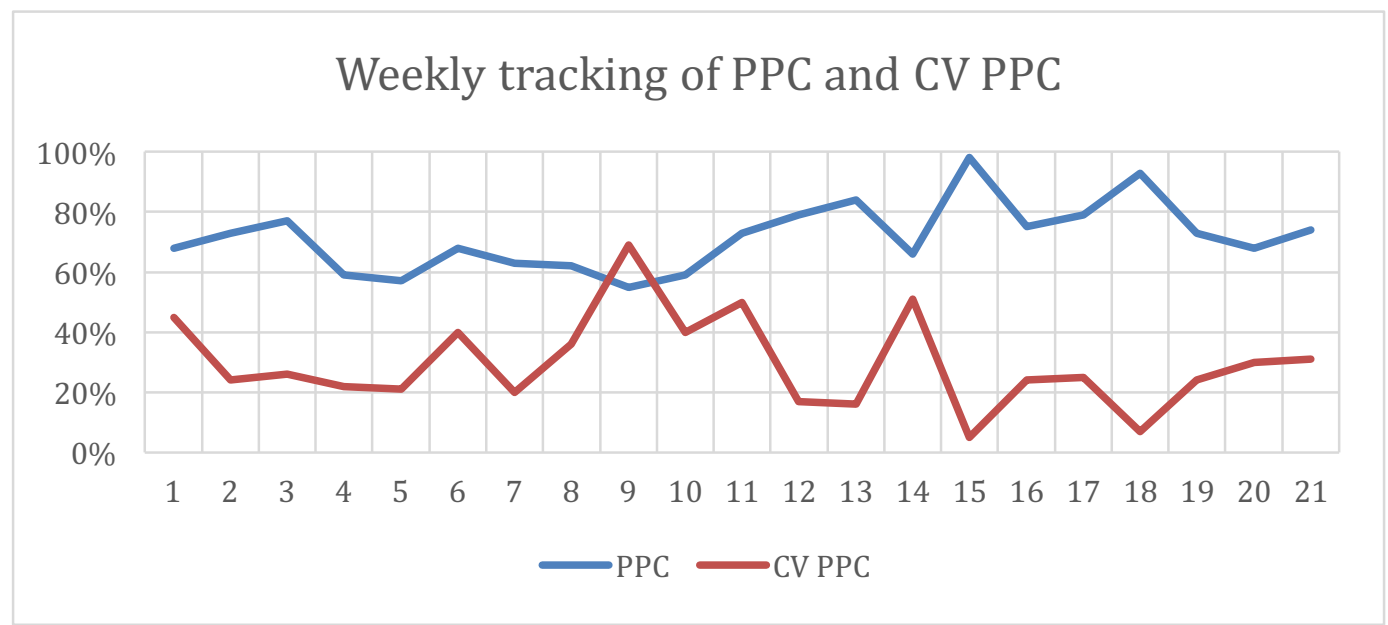

Figure 3: Weekly tracking of PPC and its CV 
From the correlation analysis performed it can be stated that there is a statistical significant relationship between these two variables, with a coefficient of determination $\left(\mathrm{R}^{2}\right)$ of 0.4097 . The Pearson coefficient is -0.629 , with a significance level of 0.01 . Considering a level of significance of 0.05 , it can be stated that this relationship is statistically significant.

\section{CONCLUSIONS}

From the results of this research, we can indicate that the implementation of lean methods in underground mining development projects in execution positively impacts its performance. In particular, the results of this research indicate that the implementation of lean methodologies in this type of projects produces positive and statistically significant impacts with respect to the improvement of the mean. This stands for all the variables measured in this research and that were subjected to statistical analysis.

On the other hand, the results of this research indicate that the implementation of lean methods in this type of project produce a statistically significant reduction of the variability in project performance for certain indicators. Moreover, there was a considerable reduction in the $\mathrm{CV}$, which indicates more stable processes. In addition, this research ratifies the results found in the literature: there is a statistically significant relationship between PPC and its CV.

Even though the results from this implementation were positive, there are some limitations. For instance, it was not guaranteed that the results were sustain in time after the implementation took place. As well, the use of a small sample size limits the results. For example, the correlation of the PPC and its CV might be robustly validated with greater sample data. Regarding future studies and researches, they might focus on extending and enhancing the analysis in this research. For example, the addition of other indicators, such as safety ones, might be considered.

\section{ACKNOWLEDGMENTS}

The authors want to thank DICTUC of Pontificia Universidad Católica de Chile and CODELCO for providing the opportunity to carry out this research.

\section{REFERENCES}

Ade, M. \& Deshpande, V.S., 2012. Lean manufacturing and productivity improvement in coal mining industry. International Journal of Engineering Research and Development, 2(10), pp.35-43.

Alarcón, L.F. et al., 2008. Assessing the impacts of implementing lean construction. Revista Ingenieria de Construccion, 23(January), pp.26-33.

Arzaluz, S., 2005. La utilización del estudio de caso en el análisis local. Revista Región y Sociedad, XVII(32), p.2005.

Ballard, G., 2005. Construction: One type of project production system. In Proceedings for the 13th Annual Conference of the International Group for Lean Construction, IGLC 13. SYdney, NSW, pp. 29-35.

Ballard, G., 2000. The last planner system of production control. Ph.D. dissertation, University of Birmingham, Birmingham, UK.

Ballard, G. \& Howell, G., 1994. Implementing lean construction: Improving downstream performance. In Lean Construction. Rotterdam, Netherlands, pp. 111-125. 
Castillo, G., Alarcón, L.F. \& González, V., 2015. Implementing lean production in copper mining development projects: case study. Jorunal of Construction and Engineering Management, 141(1).

Dunstan, K., Lavin, B. \& Sanford, R., 2006. The application of lean manufacturing in a mining environment. International Mine Management, October 16, pp.145-157.

Goode, W. \& Hatt, P., 2008. Métodos de investigación social tercera ed., Mexico: Editorial F. Trilla.

Hattingh, T.S. \& Keys, O.T., 2010. How applicable is industrial engineering in mining? In The 4th International Platinum Conference, Platinum in transition "Boom or Bust." Sun City, South Africa: The Southern African Institute of Mining and Metallurgy, pp. 205-210.

Klippel, A., Petter, C. \& Antunes, J., 2008a. Lean management implementation in mining industries. DYNA, 75(154), pp.81-89.

Klippel, A., Petter, C. \& Antunes, J., 2008b. Management innovation, a way for mining companies to survive in a globalized world. Utilities Policy, 16(4), pp.332-333.

Koskela, L., 1992. Application of the new production philosophy to construction. Center for Integrated Facility Engineering. Department of Civil Engineering. Stanford University.

Leal, M., 2010. Impactos de la implementacion del sistema Last Planner en obras de montaje industrial en minería. Departamento de Ingeniería y Gestión de la Construcción. Pontificia Universidad Católica de Chile.

Loow, J., 2015. Lean production in mining: an overview. Department of Business Administration, Technology and Social Sciences. Lulea University of Technology.

McKinsey and Company, 2013. Productividad laboral en Chile ¿cómo estamos?, Santiago, Chile.

Pardo, A. \& San Martín, R., 1998. Análisis de datos en psicología II (2ed), Madrid: Pirámide.

Schell, C., 1992. Case study as a research method. ERS-RUPRI conference: Exploring Rural Entrepreneurship, 11(1), pp.370-388.

Shah, R. \& Ward, P.T., 2007. Defining and developing measures of lean production. Journal of Operations Management, 25(4), pp.785-805.

Simons, H., 2011. El estudio de caso: Teoría y práctica. , p.2011.

De Valence, G., 2005. Production theory and construction productivity. In Proceedings for the 13th Annual Conference of the International Group for Lean Construction, IGLC 13. Sydney, NSW, Australia, pp. 135-141.

Wijaya, R., Kumar, R. \& Kumar, U., 2009. Implementing Lean Principle into Mining Industry Issues and Challenges. , pp.1-9.

Womack, J. \& Jones, D., 1996. Lean Thinking: Banish Waste and Create Wealth in Your Corporation, New York: Simon \& Schuster.

Womack, J., Jones, D. \& Roos, D., 1990. The Machine that Changed the World:, New York: Rawson Associates.

Yin, R.K., 2003. Case study research: Design and methods Thousand O., Sage Publications. Yingling, J.C., Detty, R.B. \& Sottile, J., 2000. Lean manufacturing principles and their applicability to the mining industry. Mineral Resources Engineering, 9(2), pp.215-238. 